D) Check for updates

Cite this: Chem. Commun., 2021, 57,4556

Received 22nd January 2021, Accepted 30th March 2021

DOI: $10.1039 / \mathrm{d} 1 \mathrm{cc} 00393 \mathrm{c}$

rsc.li/chemcomm

\section{A photochemical ring expansion of 6- to 8-membered nitrogen heterocycles by $[1,3]$-sigmatropic rearrangement + \%}

\author{
Morgan A. Manning, Wei Sun, Mark E. Light and David C. Harrowven (D)*
}

\begin{abstract}
A new route to azocines and benzoazocines from furopyridinones is described through a photochemically induced [1,3]-sigmatropic rearrangement. The method gives access to these 8 -membered nitrogen heterocycles from dimethyl squarate in four stages and with excellent atom economy by sequencing thermal and photochemical ring expansion steps under continuous flow.
\end{abstract}

Azocanes and their unsaturated analogues form a class of 8membered nitrogen heterocycles that includes the manzamine alkaloids and other natural products. ${ }^{1-5}$ Though they have the attributes of a privileged structure in medicinal chemistry, ${ }^{6}$ they remain underexploited in that context due to challenges associated with their synthesis. ${ }^{7}$ In particular, syntheses based on 'end-to-end' cyclisation strategies have to overcome transannular strain and the loss of entropy on ring closure, ${ }^{3,7,8}$ making it necessary to employ high dilution or pseudo-high dilution conditions to reduce competing intermolecular reactions. ${ }^{9}$ Herein we describe a new route to azocines 3 and benzoazocines 6 by photo-induced ring expansion of vinyl- and aryl-furopyridinones 2 and 5 respectively (Scheme 1). ${ }^{10,11}$ In addition we show how the same products can be formed directly from alkynylcyclobutenones $\mathbf{1}$ and $\mathbf{4}$ by sequencing thermal and photochemical rearrangements under flow. ${ }^{11,12}$

The discovered was made during a follow-up study on the thermal rearrangement of aminocyclobutenones $\mathbf{1} / \mathbf{4}$ to furopyridinones $2 / \mathbf{5}^{10,12}$ The presence of an extended chromophore in the products prompted us to examine their photochemistry. ${ }^{13}$ Pleasingly, when an acetonitrile solution of $2 \mathbf{a}$ was irradiated with UVA light ( $\lambda=370 \mathrm{~nm}, 36 \mathrm{~W}$ ) under continuous flow, using a setup akin to that described by Booker-Milburn and Berry et al. ${ }^{13-15}$ it gave furoazocine $\mathbf{3 a}$ in $48 \%$ yield (Scheme 2). Similarly,

Chemistry, University of Southampton, Highfield, Southampton, SO17 1BJ, UK. E-mail:dch2@soton.ac.uk

$\dagger$ Dedicated to Prof. Kevin Booker-Milburn on the occasion of his retirement.

\$ Electronic supplementary information (ESI) available: Experimental accounts, spectral and analytical details together with copies of ${ }^{1} \mathrm{H}$ and ${ }^{13} \mathrm{C}$ NMR spectra. CCDC 1969077 and 2025763. For ESI and crystallographic data in CIF or other electronic format see DOI: 10.1039/d1cc00393c furopyridinones $\mathbf{2 b}$ and $2 \mathbf{c}$ gave furoazocines $\mathbf{3 b}$ and $\mathbf{3 c}$ in $47 \%$ and $54 \%$ yield respectively on irradiation.

Attention next turned to aryl-substituted furopyridinones $\mathbf{5 a}-\mathbf{h}$, which were readily prepared by thermal rearrangement of the corresponding alkynylcyclobutenones 4 (Scheme 4 and ESI $¥){ }^{10}$ Each underwent ring expansion on irradiation with UVA to give the corresponding benzoazocines $\mathbf{6 a - h}$ (Tables 1 and 2) with a skipped diene unit. Yields were typically in the range of $51-74 \%$, except for substrate $\mathbf{5 h}$ with the electron deficient arene which was significantly lower (28\%). Cases where the migrating bond was between two benzylic centres, e.g. 5i-n (Table 2), were also high yielding and notably gave benzoazocines $\mathbf{6} \mathbf{i}-\mathbf{n}$ as single diastereoisomers. Their relative stereochemistry was confirmed by x-ray crystallographic analysis of $6 \mathbf{i}$ and $\mathbf{6 l}$ (Fig. 1).

The mechanistic course of the reaction was next examined by TD-DFT, ${ }^{18}$ using $\mathbf{5 a} \rightarrow \mathbf{6 a}$ as the exemplar. Calculations showed that the singlet excited state ${ }^{1}[\mathbf{5 a}]^{*}$ could relax directly to azocine 7a via a 1,3-sigmatropic rearrangement (Fig. 2), ${ }^{19}$ before giving benzoazocine 6a via a thermal [1,5]-sigmatropic $\mathrm{H}$-shift (estimated $E_{\mathrm{a}}=16.0 \mathrm{kcal} \mathrm{mol}^{-1}$ ). ${ }^{20}$

Interestingly, for the related thiophene derivative $\mathbf{5 n}$ the conjugated tetraene $\mathbf{7 n}$ was evidenced as an intermediate by ${ }^{1} \mathrm{H}$ NMR, albeit as a mixture with $\mathbf{6 n}$. On standing that sample underwent isomerization to give tris-heterocycle $\mathbf{6 n}$ as the sole

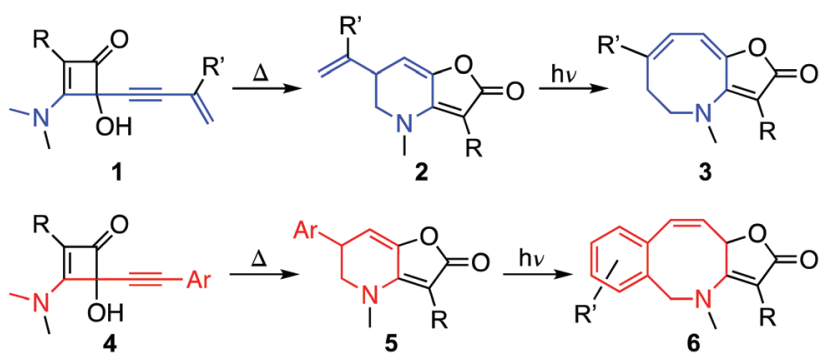

Scheme 1 Sequential thermal and photochemical ring expansion reactions for the synthesis of azocines and benzoazocines from cyclobutenones. 
<smiles>C=C(C)C1C=C2OC(=O)C(Br)=C2N([14CH3])C1</smiles>
2a<smiles>CC1=CC=C2OC(=O)C(Br)=C2N(C)CC1</smiles>

3a, $48 \%$<smiles>C=C(C)C1C=C2OC(=O)C(C)=C2N(Cc2ccccc2)C1c1ccccc1</smiles>

2b

3b, $47 \%$

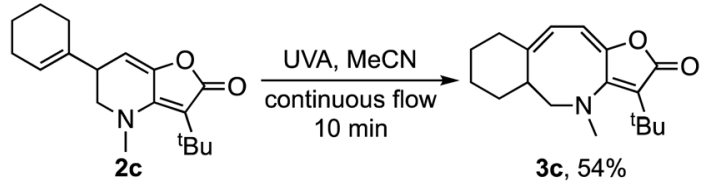

Scheme 2 Photochemical ring expansions of furopyridinones to azocines. ${ }^{16,17}$

Table 1 Benzoazocines from furopyridinones following UVA irradiation

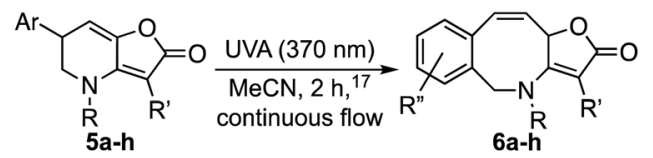<smiles>CC1=C2C(/C=C\c3ccccc3CN2C)OC1=O</smiles><smiles>CC1=C2C(=O)C(=O)OC2C=Cc2ccccc2CN1Br</smiles>

6b, $70 \%$<smiles>CN1Cc2ccccc2C=CC2OC(=O)C([AsH2-])=C21</smiles><smiles>CN1Cc2ccccc2C=CC2OC(=O)C(Br)=C21</smiles>

$6 e, 57 \%$

$6 d, 52 \%$<smiles>COc1cc2c(c(OC)c1OC)/C=C\C1OC(=O)C(C(C)Br)=C1N(C)C2</smiles>

$6 \mathrm{~g}, 70 \%$<smiles>CN1Cc2cc(C(F)(F)F)ccc2C=CC2OC(=O)C(Br)=C21</smiles>

6 h, $28 \%$ product (Scheme 3). TD-DFT analysis indicated that the barrier for the $[1,5]$-H-shift, $7 \mathbf{n} \rightarrow \mathbf{6 n}\left(26.7 \mathrm{kcal} \mathrm{mol}^{-1}\right.$, see ESI $\left.\$\right)$, was significantly higher than for $7 \mathbf{a} \rightarrow \mathbf{6 a}$, suggesting that isomerization may be by protonation and deprotonation in this case. The method was then extended to the 2-thiophenyl and 3-pyridyl analogues, 50 and 5p with both giving a tris-heterocyclic product, 60 and 6p, albeit in low yield with the electron deficient heteroaromatic (Scheme 4).

Finally, we have been able to produce benzoazocines 6 from alkynylcyclobutenones $\mathbf{4}$, directly and in high yield, by sequencing the respective thermal and photochemical rearrangements under flow (Scheme 5). Thus, dioxane solutions of cyclobutenones $4 \mathbf{a}, \mathbf{e}, \mathbf{g}, \mathbf{i}, \mathbf{l}$ were first subjected to thermolysis at $210{ }^{\circ} \mathrm{C}$ for a residence time of $100 \mathrm{~min}$, then irradiated with UVA light from $6 \times 1.7 \mathrm{~W}$ LEDs for $10 \mathrm{~min}$ to give the corresponding benzoazocines $\mathbf{6 a}, \mathbf{e}, \mathbf{g}, \mathbf{i}, \mathbf{1}$ in $74-84 \%$ yield. Notably, the efficiency with which each starting material was prepared ensured that these four-stage sequences from dimethyl squarate 8 each proceeded in $\sim 50 \%$ overall yield. ${ }^{21}$
2

Table 2 Photochemical rearrangements of diarylfuropyridinones
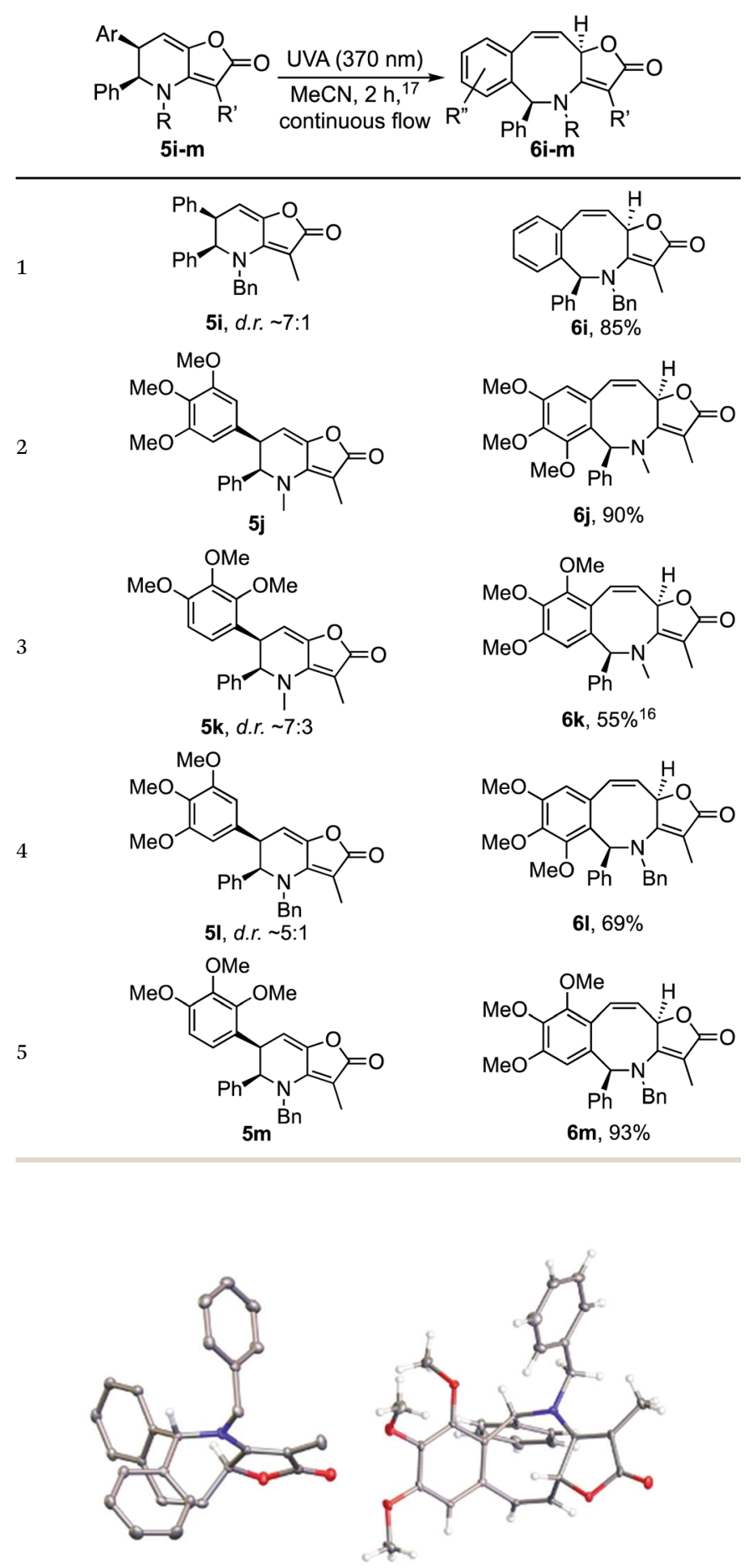

Fig. 1 X-Ray crystal structures of benzoazocines $6 \mathbf{i}[C C D C 1969077 \$]$ and 6l [CCDC 2025763\$].

Sequential thermal and photochemical rearrangements were also effective with alkynylcyclobutenone 1c (Scheme 6). In this case it was found advantageous to conduct the thermolysis in two stages due to its poor conversion to the intermediate furopyridinone $2 \mathrm{c}$ following a single pass at $160{ }^{\circ} \mathrm{C}$. As with the aforementioned examples, the overall yield of azocine 


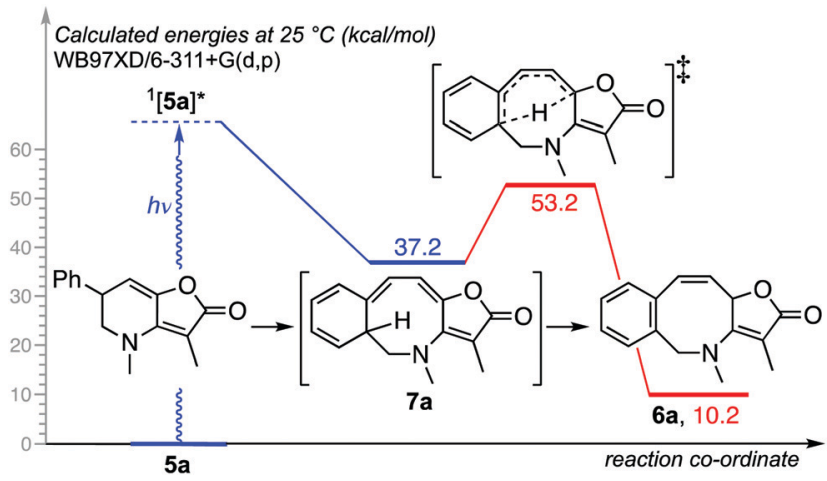

Fig. 2 Calculated free energy barriers for the rearrangement of $\mathbf{5 a}$.

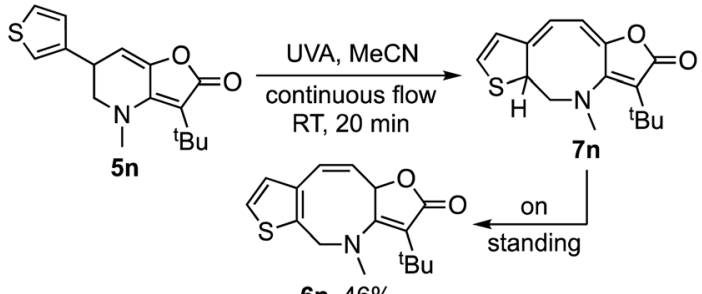

$6 n, 46 \%$

Scheme 3 Evidence for the intermediacy of polyene 7 was provided by extension to the heteroaromatic analogue $\mathbf{5 n} .^{17}$
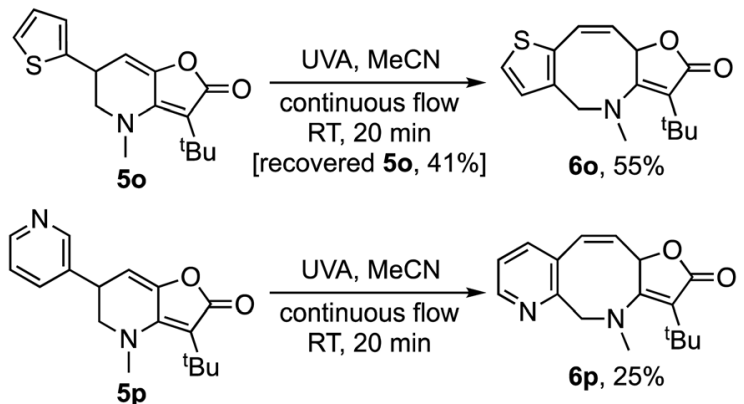

Scheme 4 Further examples involving heteroaromatic ring systems. ${ }^{17}$

3c given after sequencing these steps under continuous flow was substantially higher than that achieve using stepwise procedures. $^{21}$

In conclusion, we have developed a new route to azocines and benzoazocines involving the photochemical ring expansion of furopyridinones. The ease with which these products can be prepared from dimethyl squarate $\mathbf{8}$ in high yield and diastereoselectivity, and with excellent atom economy, makes this an attractive entry to a class of nitrogen heterocycles that is difficult to access using classical procedures.

Dr Wei Sun and Morgan Manning contributed equally in respect of the experimental work, with Dr Mark Light performing the X-ray analyses and Prof. David Harrowven supervising the work.

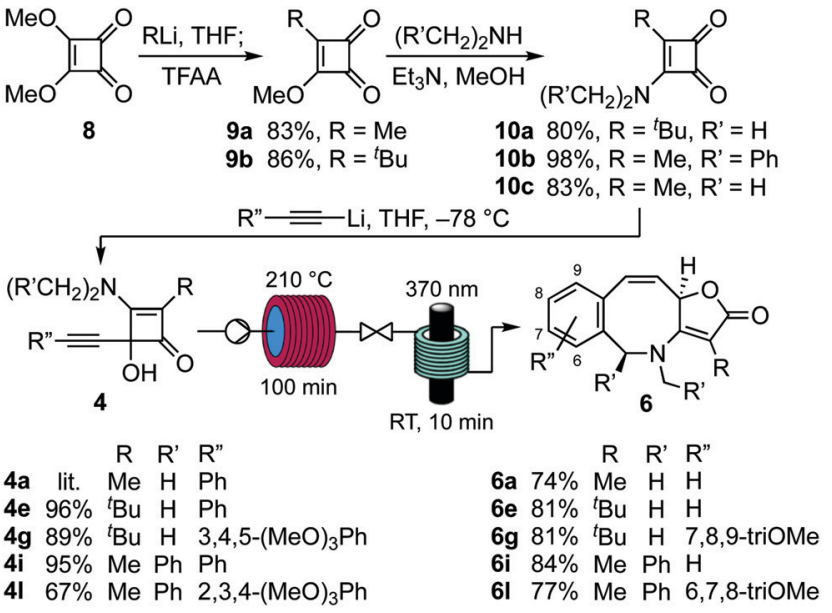

Scheme 5 Preparation of cyclobutenones 4 and conversion to benzoazocines 6 by sequenced thermal and photochemical rearrangement under continuous flow.

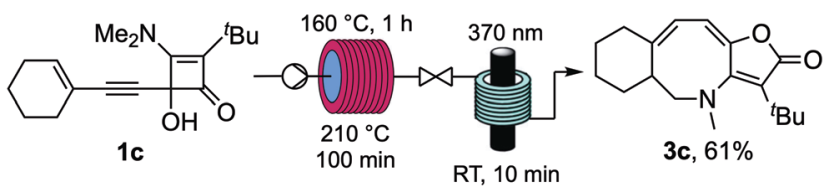

Scheme 6 Sequenced thermal and photochemical rearrangement of cyclobutenone $1 \mathrm{c}$ to azocine $3 \mathrm{c}$ under continuous flow.

We gratefully acknowledge financial support from the European Regional Development Fund [ERDF Interreg Va programme (Project 121)] and EPSRC [EP/P013341/1, EP/L003325/1 and EP/ K039466/1].

\section{Conflicts of interest}

There are no conflicts of interest to declare.

\section{Notes and references}

1 R. Sakai, T. Higa, C. W. Jefford and G. Bernardinelli, J. Am. Chem. Soc., 1986, 108, 6404; P. Jakubec, A. Hawkins, W. Felzmann and D. J. Dixon, J. Am. Chem. Soc., 2012, 134, 17482; J. E. Baldwin, T. D. W. Claridge, F. A. Heupel and R. C. Whitehead, Tetrahedron Lett., 1992, 33, 2059; P. Jakubec, A. F. Kyle, J. Calleja and D. J. Dixon, Tetrahedron Lett., 2011, 52, 6094; J. D. Winkler and J. M. Axten, J. Am. Chem. Soc., 1998, 120, 6425; M. Nakagawa, J. Heterocycl. Chem., 2000, 37, 567; S. F. Martin, J. M. Humphrey, A. Ali and M. C. Hillier, J. Am. Chem. Soc., 1999, 121, 866; J. M. Humphrey, Y. Liao, A. Ali, T. Rein, Y. L. Wong, H. J. Chen, A. K. Courtney and S. F. Martin, J. Am. Chem. Soc., 2002, 124, 8584; T. Toma, Y. Kita and T. Fukuyama, J. Am. Chem. Soc., 2010, 132, 10233; J. E. Baldwin, T. D. W. Claridge, A. J. Culshaw, F. A. Heupel, V. Lee, D. R. Spring and R. C. Whitehead, Chem. - Eur. J., 1999, 5, 3154; B. Zhang, R. Higuchi, T. Miyamoto and R. W. M. Van Soest, Chem. Pharm. Bull., 2008, 56, 866; Y. Kita, T. Toma, T. Kan and T. Fukuyama, Org. Lett., 2008, 10, 3251; R. A. Stockman, P. J. McDermott, A. F. Newton and P. Magnus, Synlett, 2010, 559.

2 Lundurine A and B: A. Nash, X. Qi, P. Maity, K. Owens and U. K. Tambar, Angew. Chem., Int. Ed., 2018, 57, 6888; S. Jin, J. Gong and Y. Qin, Angew. Chem., Int. Ed., 2015, 54, 2228; M. Hoshi, O. Kaneko, M. Nakajima, S. Arai and A. Nishida, Org. 
Lett., 2014, 16, 768Nakadomarin A: P. Jakubec, D. M. Cockfield and D. J. Dixon, J. Am. Chem. Soc., 2009, 131, 16632; P. Jakubec, A. F. Kyle, J. Calleja and D. J. Dixon, Tetrahedron Lett., 2011, 52, 6094; J. N. I. Kobayashi, D. Watanabe, N. Kawasaki and M. Tsuda, J. Org. Chem., 1997, 62, 9236; J. Kobayashi, Pure Appl. Chem., 1999, 71, 1123; I. S. Young and M. A. Kerr, J. Am. Chem. Soc., 2007, 129, 1465.

3 Buflavine: C. Hoarau, A. Couture, E. Deniau and P. Grandclaudon, J. Org. Chem., 2002, 67, 5846; P. Sahakitpichan and S. Ruchirawat, Tetrahedron Lett., 2003, 44, 5239; F. Viladomat, J. Bastida, C. Codina, W. E. Campbell and S. Mathee, Phytochemistry, 1995, 40, 307; P. A. Patil and V. Snieckus, Tetrahedron Lett., 1998, 39, 1325; Y. Ishida, Y. Sasaki, Y. Kimura and K. Watanabe, J. PharmacobioDyn, 1985, 8, 917; S. Kobayashi, M. Kihara, S. Shizu, S. Katayama, H. Ikeda, K. Kitahiro and H. Matsumoto, Chem. Pharm. Bull., 1977, 25, 3312 .

4 Magallanesine: E. Valencia, V. Fajardo, A. J. Freyer and M. Shamma, Tetrahedron Lett., 1985, 26, 993; R. Yoneda, Y. Sakamoto, Y. Oketo, K. Minami, S. Harusawa and T. Kurihara, Tetrahedron Lett., 1994, 35, 3749; R. Yoneda, Y. Sakamoto, Y. Oketo, S. Harusawa and T. Kurihara, Tetrahedron, 1996, 52, 14563; F. G. Fang, G. B. Feigelson and S. J. Danishefsky, Tetrahedron Lett., 1989, 30, 2743 .

5 Apparicine: M. L. Bennasar, E. Zulaica, D. Solé and S. Alonso, Chem. Commun., 2009, 3372; M. L. Bennasar, E. Zulaica, D. Solé, T. Roca, D. García-Díaz and S. Alonso, J. Org. Chem., 2009, 74, 8359.

6 C. Zhao, Z. Ye, Z. Ma, S. A. Wildman, S. A. Blaszczyk, L. Hu, I. A. Guizei and W. Tang, Nat. Commun., 2019, 10, 4015; A. Hussain, S. K. Yousuf and D. Mukherjee, RSC Adv., 2014, 4, 43241; R. A. Bauer, T. A. Wenderski and D. S. Tan, Nat. Chem. Biol., 2013, 9, 21; A. Sharma, P. Appukkuttan and E. Van Der Eycken, Chem. Commun., 2012, 48, 1623; K. R. Romines, K. D. Watenpaugh, P. K. Tomich, W. J. Howe, J. K. Morris, K. D. Lovasz, A. M. Mulichak, B. C. Finzel, J. C. Lynn, M. M. Homg, F. J. Schwende, M. J. Ruwart, G. L. Zipp, K. T. Chong, L. A. Dolak, L. N. Toth, G. M. Howard, B. D. Rush, K. F. Wilkinson, P. L. Possert, R. J. Dalga and R. R. Hinshaw, J. Med. Chem., 1995, 38, 1884; E. D. Thorsett, E. E. Harris, S. D. Aster, E. R. Peterson, J. P. Snyder, J. P. Springer, J. Hirshfield, E. W. Tristram, A. A. Patchett, E. H. Ulm and T. C. Vassil, J. Med. Chem., 1986, 29, 251; M. E. Rogers, H. H. Ong, E. L. May and W. A. Klee, J. Med. Chem., 1975, 18, 1036; H. H. Ong and E. L. May, J. Org. Chem., 1973, 38, 924; E. J. Lien, L. L. Lien and G. L. Tong, J. Med. Chem., 1971, 14, 846.

7 A. K. Clarke and W. P. Unsworth, Chem. Sci., 2020, 11, 2876; J. R. Donald and W. P. Unsworth, Chem. - Eur. J., 2017, 23, 8780; A. V. Listratova and L. G. Voskressensky, Synthesis, 2017, 3801; A. Deiters and S. F. Martin, Chem. Rev., 2004, 104, 2199; M. E. Maier, Angew. Chem., Int. Ed., 2000, 39, 2073; L. Yet, Chem. Rev., 2000, 100, 2963; P. A. Evans and B. Holmes, Tetrahedron, 1991, 47, 9131; C. J. Roxburgh, Tetrahedron, 1993, 49, 10749; G. Illuminati and L. Mandolini, Acc. Chem. Res., 1981, 14, 95; M. L. Bennasar, E. Zulaica, D. Solé and S. Alonso, Tetrahedron, 2007, 63, 861.

8 A. Hussain, S. K. Yousuf and D. Mukherjee, RSC Adv., 2014, 4, 43241; G. A. Molander, Acc. Chem. Res., 1998, 31, 603; M. A. Casadei, C. Galli and L. Mandolini, J. Am. Chem. Soc., 1984, 106, 1051; H. Jacobson and W. H. Stockmayer, J. Chem. Phys., 1950, 18, 1600.

9 C. J. White and A. K. Yudin, Nat. Chem., 2011, 3, 509; K. C. Majumdar, $R S C A d v$., 2011, 1, 1152; H. Bieräugel, T. P. Jansen, H. E. Schoemaker, H. Hiemstra and J. H. van Maarseveen, Org. Lett., 2002, 4, 2673; G. Rousseau, Tetrahedron, 1995, 51, 2777; J. Fastrez, J. Phys. Chem., 1989, 93, 2635; M. Antonietta Casadei, C. Galli and L. Mandolini, J. Org. Chem., 1981, 46, 3127.

10 W. Sun, D. C. Wilson, M. E. Light and D. C. Harrowven, Org. Lett., 2018, 20, 4346; W. Sun, D. C. Wilson and D. C. Harrowven, Synthesis, 2017, 3091See also: T. C. Stephens and W. P. Unsworth, Synlett, 2020, 133; L. G. Baud, M. A. Manning, H. L. Arkless, T. C. Stephens and W. P. Unsworth, Chem. - Eur. J., 2017, 23, 2225; D. C. Harrowven, N. L'Helias, J. D. Moseley, N. J. Blumire and S. R. Flanagan, Chem. Commun., 2003, 2658.

11 J. P. Knowles, L. D. Elliott and K. I. Booker-Milburn, Beilstein J. Org. Chem., 2012, 8, 2025; K. Gilmore and P. H. Seeberger, Chem. Rec., 2014, 14, 410; C. Sambiagio and T. Noël, Trends Chem., 2020, 2, 92; M. B. Plutschack, B. Pieber, K. Gilmore and P. H. Seeberger, Chem.
Rev., 2017, 117, 11796; D. Cambié, C. Bottecchia, N. J. W. Straathof, V. Hessel and T. Noël, Chem. Rev., 2016, 116, 10276; F. Politano and G. Oksdath-Mansilla, Org. Process Res. Dev., 2018, 22, 1045; T. H. Rehm, ChemPhotoChem, 2019, 3, 1; N. Hoffmann, Chem. Rev., 2008, 108, 1052; M. Oelgemoeller, Chem. Eng. Technol., 2012, 35, 1144.

12 E. Packard, D. D. Pascoe, J. Maddaluno, T. P. Gonçalves and D. C. Harrowven, Angew. Chem., Int. Ed., 2013, 52, 13076; D. C. Harrowven, M. Mohamed, T. P. Gonçalves, R. J. Whitby, D. Bolien and H. F. Sneddon, Angew. Chem., Int. Ed., 2012, 51, 4405; M. Mohamed, T. P. Gonçalves, R. J. Whitby, H. F. Sneddon and D. C. Harrowven, Chem. - Eur. J., 2011, 17, 13698; D. C. Harrowven, D. D. Pascoe, D. Demurtas and H. O. Bourne, Angew. Chem., Int. Ed., 2005, 44, 1221.

13 T. P. Gonçalves, M. Mohamed, R. J. Whitby, H. F. Sneddon and D. C. Harrowven, Angew. Chem., Int. Ed., 2015, 54, 4531; D. E. Collin, E. H. Jackman, N. Jouandon, W. Sun, M. E. Light, D. C. Harrowven and B. Linclau, Synthesis, 2021, 1307.

14 B. D. A. Hook, W. Dohle, P. R. Hirst, M. Pickworth, M. B. Berry and K. I. Booker-Milburn, J. Org. Chem., 2005, 70, 7558.

15 L. D. Elliott, M. Berry, B. Harji, D. Klauber, J. Leonard and K. I. Booker-Milburn, Org. Process Res. Dev., 2016, 20, 1806; C. A. Clark, D. S. Lee, S. J. Pickering, M. Poliakoff and M. W. George, Org. Process Res. Dev., 2016, 20, 1792; L. D. Elliott, J. P. Knowles, P. J. Koovits, K. G. Maskill, M. J. Ralph, G. Lejeune, L. J. Edwards, R. I. Robinson, I. R. Clemens, B. Cox, D. D. Pascoe, G. Koch, M. Eberle, M. B. Berry and K. I. Booker-Milburn, Chem. Eur. J., 2014, 20, 15226.

16 Examples of the rearrangements $2 \rightarrow 3$ were limited by the availability of enynes from commercial suppliers, and on-going COVID restrictions. Compound 6k was contaminated with an unknown impurity accounting for $c a$. $5 \%$ of its mass.

17 The photochemical experiments described in Tables 1 and 2 were conducted using a $36 \mathrm{~W}$ Philips UVA lamp [PL36/10/4P] that delivered $\sim 10 \mathrm{~W}$ UVA irradiation for a reactor volume of $120 \mathrm{~mL}$ [UVA irradiation density $\sim 0.08 \mathrm{~W} \mathrm{~mL}^{-1}$ ]. In Schemes $2-6$, a bespoke UVA LED reactor was used that delivered $\sim 12 \mathrm{~W}$ UVA irradiation for a reactor volume of $10 \mathrm{~mL}$. The irradiation density in this case was substantially higher at $\sim 1.2 \mathrm{~W} \mathrm{~mL}^{-1}$. See ESI for details.

18 K. G. Maskill, J. P. Knowles, L. D. Elliott, R. W. Alder and K. I. Booker-Milburn, Angew. Chem., Int. Ed., 2013, 52, 1499.

19 A. C. Cope, M. M. Martin and M. A. McKervey, Q. Rev. Chem. Soc., 1966, 20, 119; R. B. Woodward and R. Hoffmann, J. Am. Chem. Soc., 1965, 87, 2511; R. Hoffmann and R. B. Woodward, Acc. Chem. Res., 1968, 1, 17; R. B. Woodward and R. Hoffmann, Angew. Chem., Int. Ed. Engl., 1969, 8, 781; N. G. Rondon and K. N. Houk, Tetrahedron Lett., 1984, 25, 2519; J. E. Baldwin, P. A. Leber and T. W. Lee, J. Org. Chem., 2001, 66, 5269; B. A. Hess and J. E. Baldwin, J. Org. Chem., 2002, 67, 6025; P. Rademacher and P. Choudhary Mohr, Org. Biomol. Chem., 2007, 5, 2698; L. Stéhelin, J. Lhomme and G. Ourisson, J. Am. Chem. Soc., 1971, 93, 1650.

20 M. J. Frisch, G. W. Trucks, H. B. Schlegel, G. E. Scuseria, M. A. Robb, J. R. Cheeseman, G. Scalmani, V. Barone, B. Mennucci, G. A. Petersson, H. Nakatsuji, M. Caricato, X. Li, H. P. Hratchian, A. F. Izmaylov, J. Bloino, G. Zheng, J. L. Sonnenberg, M. Hada, M. Ehara, K. Toyota, R. Fukuda, J. Hasegawa, M. Ishida, T. Nakajima, Y. Honda, O. Kitao, H. Nakai, T. Vreven, J. A. Montgomery Jr., J. E. Peralta, F. Ogliaro, M. Bearpark, J. J. Heyd, E. Brothers, K. N. Kudin, V. N. Staroverov, R. Kobayashi, J. Normand, K. Raghavachari, A. Rendell, J. C. Burant, S. S. Iyengar, J. Tomasi, M. Cossi, N. Rega, N. J. Millam, M. Klene, J. E. Knox, J. B. Cross, V. Bakken, C. Adamo, J. Jaramillo, R. Gomperts, R. E. Stratmann, O. Yazyev, A. J. Austin, R. Cammi, C. Pomelli, J. W. Ochterski, R. L. Martin, K. Morokuma, V. G. Zakrzewski, G. A. Voth, P. Salvador, J. J. Dannenberg, S. Dapprich, A. D. Daniels, Ö. Farkas, J. B. Foresman, J. V. Ortiz, J. Cioslowski and D. J. Fox, Gaussian 09, Revision A.02, Gaussian, Inc., Wallingford CT, 2009.

21 A significant loss of mass balance to mixed fractions occurs on purification of furopyridinones 2 and 5 by column chromatography. We believe this to be the primary reason for the yield elevation observed when the thermal and photochemical steps are sequenced. 